\title{
KEBUTUHAN ENERGI GIZI DALAM TUBUH
}

\section{Futri Alifia Rezkiyanti}

\section{Universitas Islam Negeri Alauddin Makassar}

Email : futrialifia@gmail.com

\section{KEBUTUHAN ENERGI GIZI}

Tubuh memerlukan energi sebagai sumber tenaga untuk segala aktivitas. Energi diperoleh dari makanan sehari-hari yang terdiri dari berbagai zat gizi terutama karbohidrat dan lemak. Energi yang dipergunakan untuk melakukan pekerjaan, dilepaskan dalam tubuh pada proses pembakaran zat-zat makanan. Dengan mengukur jumlah energi yang dikeluarkan itu dapat diketahui berapa banyak makanan yang diperlukan untuk menghasilkannya. Kebutuhan energi seseorang adalah konsumsi energi dari makanan yang diperlukan untuk menutupi pengeluaran energi seseorang.

\section{Karbohidrat}

Karbohidrat merupakan komponen makanan sebagai sumber energi utama yang mudah dicerna dan cepat bisa digunakan. Kebutuhan energi karbohidrat ini sebesar kisaran 55-67\% dari seluruh total kalori.

\section{Lemak}

Merupakan zat makanan yang tidak larut didalam air. Namun mereka dicerna menjadi sumber energi cadangan setelah otot menghabiskan sebagian besar glikogennya. Lemak disimpan di dalam tubuh disekitar organ tubuh dan dalam jumlah besar disimpan di bawah kulit. Kebutuhan energi yang berasal dari lemak $+20-30 \%$ dari total kalori perhari.

\section{Protein}

Protein adalah suatu zat organik yang membentuk utama sel dan jaringan. Tubuh tidak dapat menyimpan kelebihan protein. Namun protein menjadi sumber energi secara tidak langsung dengan sejalannya aktivitas meningkat guna pembentukan dan membangun sel dan jaringan baru setelah rusak akibat berbagai aktivitas. Kebutuhan energi berasal dari protein $13-15 \%$ dari total kalori per hari. 


\section{KEBUTUHAN ENERGI GIZI IBU HAMIL}

Tambahan energi yang dibutuhkan ibu hamil usia dewasa dengan status gizi baik pada saat pra hamil, serta aktivitas fisik ringan untuk trimester I hampir tidak diperlukan energi tambahan, trimester II dibutuhkan 300-350 kkal/hari, dan trimester III dibutuhkan tambahan energi sebesar 450-500 kkal/hari.

Ibu yang sedang hamil membutuhkan tambahan energi/kalori untuk tumbuh kembang janin, plasenta, jaringan payudara, cadangan lemak, serta untuk perubahan metabolisme yang terjadi. Pada trimester II dan III, kebutuhan kalori tambahan ini berkisar 300 kalori per hari dibanding saat tidak hamil. Berdasarkan perhitungan, pada akhir kehamilan dibutuhkan sekitar 80.000 kalori lebih banyak dari kebutuhan kalori sebelum hamil.

\section{KEBUTUHAN ENERGI GIZI IBU MENYUSUI}

Kebutuhan Nutrisi ibu menyusui meliputi Kebutuhan Energi , untuk memproduksi air susu ibu baru (ASI), ibu menyusui perlu tambahan energi yang bersumber dari makanan sebesar 330 kkal pada enam bulan pertama dan 400 Kkal pada enam bulan kedua dan 100- 150 Kkal dari lemak cadangan tubuh ibu sendiri. Karena lemak tubuh dipakai maka BB ibu post partum turun 0,5 sampai dengan $1 \mathrm{~kg} /$ bulan.

\section{KEBUTUHAN ENERGI GIZI BAYI}

Dalam usia bayi 0-6 bulan, makanan yang paling tepat untuk bayi adalah air susu ibu atau ASI, karena memang komposisi zat gizi yang ada pada ASI paling tepat untuk bayi pada usia ini. Jika pada usia satu bulan pertama produksi ASI mencapai sekitar 500 mili liter per hari, memasuki bulan kedua dan ketiga produksi ASI dapat naik sampai sekitar 650 mililiter per hari. Apabila tiap $100 \mathrm{ml}$ ASI memberikan 75 kalori, berarti dari ASI bayi hanya akan memperoleh 450 kalori, sedangkan jumlah kebutuhan adalah sekitar 750 kalori, jadi masih kurang sebesar 300 kalori, dan kekurangan ini dapat dipenuhi dari makanan tambahan lain. Pada usia 9-12 bulan kebutuhan kalori bayi adalah $350 \mathrm{kal}$ (dari $500 \mathrm{ml}$ ASI). Sehingga diperlukan tambahan makanan sebesar 450-500 kalori per hari.

\section{KEBUTUHAN ENERGI GIZI ANAK}

Kebutuhan gizi balita meliputi : Asupan makanan sehari untuk anak harus mengandung 10-15\% kalori, 20-35\% lemak, dan sisanya karbohidrat. Setiap kg berat badan anak memerlukan asupan energi sebanyak $100 \mathrm{kkal}$. Asupan lemak juga perlu ditingkatkan karena struktur utama pembentuk otak adalah lemak. 


\section{KEBUTUHAN ENERGI GIZI REMAJA}

Energi sangat diperlukan dalam jumlah banyak untuk pertumbuhan dan aktivitas yang memasuki periode tumbuh cepat. Kebutuhan energi pada remaja dipengaruhi oleh energi basal, jenis kelamin, faktor aktivitas, dan adanya penyakit. Semua kebutuhan zat gizi meningkat pada masa remaja. Jumlah zat gizi yang dibutuhkan ini disesuaikan dengan daftar Angka Kecukupan Gizi (AKG). Protein; seimbang (1gr/kgBB/hr). Mineral Fe \& Ca kebutuhannya 800-1200 $\mathrm{mg} / \mathrm{hr}$.

\section{KEBUTUHAN ENERGI GIZI DEWASA}

Kebutuhan kalori mulai berkurang pada usia 25 tahun, tergantung pada aktivitas fisik, jenis kelamin, dan massa tubuh. Zat besi dibutuhkan oleh usia subur selama masa reproduksi, untuk menggantikan kehilangan zat besi selama menstruasi, kehamilan, kelahiran dan menyusui, kalsium juga berperan penting untuk pertulangan, mengingat kehilangan kalsium dalam massa tulang berkurang pada masa usia lanjut.

Masalah gizi pada usia dewasa meliputi: Kurang Energi Protein (KKP), Anemia pada wanita dan masalah Gizi lebih/Obesitas. Prinsip gizi seimbang dewasa : Tubuh manusia membutuhkan aneka ragam makanan yang dijamin mengandung sumber karbohidrat (nasi, roti, kentang, mie, singkong, dll), protein hewani/nabati (ikan, telur, daging, ayam, tempe, tahu, kacang-kacangan), vitamin dan mineral ( buah-buahan, sayuran), dan sumber lemak/minyak (minyak goreng, santan, mentega, margarin) dan air.

\section{KEBUTUHAN ENERGI GIZI LANSIA}

Hasil-hasil penelitian menunjukan bahwa kecepatan metabolisme basal pada orangorang berusia lanjut menurun sekitar 15-20\%, disebabkan berkurangnya massa otot dan aktivitas. Kalori (energi) diperoleh dari lemak 9,4 kal, karbohidrat 4 kal, dan protein 4 kal per gramnya. Bagi lansia komposisi energi sebaiknya 20-25\% berasal dari protein, $20 \%$ dari lemak, dan sisanya dari karbohidrat. Kebutuhan kalori untuk lansia laki-laki sebanyak 1960 kal, sedangkan untuk lansia wanita 1700 kal. Bila jumlah kalori yang dikonsumsi berlebihan, maka sebagian energi akan disimpan berupa lemak, sehingga akan timbul obesitas. Sebaliknya, bila terlalu sedikit, maka cadangan energi tubuh akan digunakan, sehingga tubuh akan menjadi kurus. 


\section{DAFTAR PUSTAKA}

1. Alam, S., \& Kartini, T. A. (2020). Islamic Parenting" Pola Asuh Anak: Tinjauan Perspektif Gizi Masyarakat".

2. Mardalena, I., \& Suryani, E. Ilmu Gizi. Modul Bahan Ajar Cetak Keperawatan, 3-4. Kementrian Kesehatan Republik Indonesia.

3. Baskora A.P.R., Sutardji, and Woro, O. (2011). Sistem Informasi Perencanaan Pola Hidup Sehat melalui Keseimbangan Aktivitas dan Asupan Makanan. Jurnal Media Ilmu Keolahragaan Indonesia 1, 181-191. 